\title{
Histone H2B
}

National Cancer Institute

\section{Source}

National Cancer Institute. Histone H2B. NCI Thesaurus. Code C17460.

Histone $\mathrm{H} 2 \mathrm{~B}$ is a core subunit of the eukaryotic nucleosome complex. Histones are basic nuclear proteins responsible for the nucleosome structure of chromatin. Repeating nucleosome units contain two molecules each of Histones $\mathrm{H} 2 \mathrm{~A}, \mathrm{H} 2 \mathrm{~B}, \mathrm{H} 3$, and $\mathrm{H} 4$ that form an octamer complex around which approximately 146 base pairs of DNA is wrapped. Linker $\mathrm{H}$ istone $\mathrm{H} 1$ interacts with DNA between nucleosome units in mediating chromatin compaction into higher order structures. $(\mathrm{NCl})$ 